NBER WORKING PAPER SERIES

\title{
CONTINGENT VALUATION ANALYSIS OF WILLINGNESS TO PAY TO REDUCE CHILDHOOD OBESITY
}

\author{
John Cawley \\ Working Paper 12510 \\ http://www.nber.org/papers/w12510 \\ NATIONAL BUREAU OF ECONOMIC RESEARCH \\ 1050 Massachusetts Avenue \\ Cambridge, MA 02138 \\ September 2006
}

I gratefully acknowledge financial support from Cornell Cooperative Extension and a Smith-Lever grant from the U.S. Department of Agriculture. I thank Rachel Dunifon, Eric Finkelstein, John Komlos, Dean Lillard, Melayne Morgan McInnes, Sean Nicholson, Greg Poe, Judy Shinogle, Josephine Swanson, the Cornell Obesity Working Group for helpful comments, and three anonymous referees. I also thank Yasamin Miller and the Survey Research Center at Cornell University for survey pre-testing and data collection. The views expressed herein are those of the author(s) and do not necessarily reflect the views of the National Bureau of Economic Research.

(C) 2006 by John Cawley. All rights reserved. Short sections of text, not to exceed two paragraphs, may be quoted without explicit permission provided that full credit, including $\odot$ notice, is given to the source. 
Contingent Valuation Analysis of Willingness to Pay To Reduce Childhood Obesity

John Cawley

NBER Working Paper No. 12510

September 2006, Revised June 2008

JEL No. I1,I18

\begin{abstract}
$\underline{\text { ABSTRACT }}$
Several recent surveys have asked Americans whether they support policies to reduce childhood obesity. There is reason for skepticism of such surveys because people are not confronted with the tax costs of such policies when they are asked whether they support them. This paper uses contingent valuation (CV), a method frequently used to estimate people's willingness to pay (WTP) for goods or services not transacted in markets, applied to unique survey data from New York State to estimate the willingness to pay to reduce childhood obesity.

The willingness to pay data correlate in predictable ways with respondent characteristics. The mean WTP for a 50\% reduction in childhood obesity is \$46.41 (95\% CI: \$33.45, \$59.15), which implies a total WTP by New York State residents of $\$ 690.6$ million (95\% CI: \$497.7, \$880.15), which is less than that implied by previous surveys that did not use $\mathrm{CV}$ methods but greater than current spending on policies to reduce childhood obesity and greater than the estimated savings in external costs. The findings provide policymakers with useful information about taxpayers' support for, and preferred budget for, anti-obesity policies.
\end{abstract}

\author{
John Cawley \\ 124 MVR Hall \\ Department of Policy Analysis and Management \\ Cornell University \\ Ithaca, NY 14853 \\ and NBER \\ jhc38@cornell.edu
}




\section{Introduction}

Over the past three decades the prevalence of overweight among American youth has risen dramatically. The Centers for Disease Control and Prevention define childhood overweight $^{2}$ as a body mass index ${ }^{3}$ (BMI) above the 95th percentile for children of the same age and gender (benchmarked against the historic BMI distribution ${ }^{4}$ ). Since 1970, the fraction overweight has almost quadrupled among children aged 6-11 years and more than doubled among adolescents aged 12-19 years (Ogden et al., 2002). As of 2003-2004, 17.1 percent of children aged 2-19 are clinically overweight, a figure more than three times greater than the Healthy People $2010^{5}$ goal of 5 percent (Ogden et al., 2006; U.S. DHHS, 2000). Public health and medical organizations have responded by encouraging the passage of a wide variety of policies aimed at preventing or reducing obesity among youths (e.g. IOM, 2005). The goal of this paper is to use the method of contingent valuation to provide evidence on the public's willingness to pay higher taxes to fund policies to reduce childhood obesity.

In part to determine how much support there is for such policies to reduce childhood obesity, several surveys have been conducted recently to determine how Americans perceive childhood obesity. A summary of these surveys is provided in Table 1. From the time of the earliest listed survey (March 2003) until the survey conducted for this paper (Feb-March 2006, the methodology of which is described in a subsequent

\footnotetext{
2 The highest weight classification for adults is "obese” but in order to avoid stigmatizing youth with that label, the highest weight classification for children is "overweight." In this paper I use the two terms interchangeably.

${ }^{3}$ Body mass index (BMI) is calculated as weight in kilograms divided by height in meters squared.

${ }^{4}$ The historic data for child and adolescent BMI-for-height come from the National Health Examination Surveys II (1963-65) and III (1966-70), and the National Health and Nutrition Examination Surveys I (1971-74) and II (1976-80); U.S. DHHS (2002), Table B.

${ }^{5}$ Healthy People 2010 states U.S. national health objectives, identifies the most significant preventable threats to health, and establishes national goals to reduce these threats by the year 2010 (U.S. DHHS, 2000).
} 
section), almost all of the surveys find that at least two-thirds of respondents indicate that childhood obesity is a "major" or "serious" problem. ${ }^{6}$

A limitation of such survey questions is that it is easy for respondents to describe any issue as a serious problem. One might be more convinced if respondents expressed a willingness to pay higher taxes in exchange for reductions in childhood obesity. A few surveys have attempted to measure this, although in ad hoc ways. In the American Public Health Association (APHA) poll of 2003, 56\% of Americans said they would support “a small increase in their local tax” to provide free fruit and vegetable snacks in school lunchrooms (Widmeyer Polling \& Research, 2003). In the Harvard Forums on Health poll of 2003, 76\% of respondents said they would support school-based policies to reduce childhood obesity if it meant an increase in their taxes, and $42 \%$ said they would pay more than $\$ 100$ a year in taxes to support such efforts (Lane, Snell, Perry \& Associates, 2003). Lee and Oliver (2005) found that $64 \%$ were willing to pay $\$ 50$ more a year in taxes to support more nutritious school lunches.

These questions, while an improvement, have limitations. First, none of the questions specified both the policy’s benefits (in terms of reductions in childhood obesity), which makes it difficult for survey respondents to evaluate such proposals. Second, the Contingent Valuation (CV) literature has established that asking a series of questions that progressively narrow the bounds on willingness-to-pay (known as the double-bounded model) provides more efficient estimates of WTP than asking a yes/no

\footnotetext{
${ }^{6}$ The exceptions are the two surveys conducted by RTI (rows 4 and 5), in which fewer than $50 \%$ of respondents responded that they thought childhood obesity was a "very serious" problem; fewer people may have agreed with that statement because it was a yes/no question about a strong opinion ("very serious" instead of "serious") instead of a question that allowed the respondent to indicate a degree of agreement.
} 
question about a willingness to pay a single amount (Hanemann, Loomis, and Kanninen, 1991).

This paper estimates willingness to pay for reductions in childhood obesity using the double-bounded Contingent Valuation model. It follows the recommendations of the NOAA committee on CV (Arrow et al., 1993) and recent guidelines for conducting CV analyses (Whitehead, 2006).

This paper explores two major research questions. First, how much are people willing to pay to reduce youth obesity? Within this over-arching question, it is explored whether willingness to pay varies with characteristics such as household income, perceptions of youth obesity, opinion of current tax levels, and political affiliation.

The benefits of such an anti-obesity policy to any given voter may vary; there may be benefits to their relatives or voters may be motivated by altruism for unrelated children. It is beyond the scope of this paper to disentangle those benefits. The goal of this paper is to measure voters' willingness to pay for such a policy, because that can help guide policymakers' decisions about whether to enact such policies and what scope of such policies voters would support.

The second research question is: how do these willingness-to-pay estimates compare to results of surveys that ask public support for anti-obesity initiatives? Are the responses to previous surveys that did not ask people to consider the costs of such policies biased in favor of finding greater support for such policies?

The results of this paper are useful for policymakers because they indicate more accurately than ever before the extent of voters' support for anti-obesity policies, and also 
can provide guidance to policymakers on how much of a tax increase voters would support in exchange for reductions in childhood obesity.

\section{The Contingent Valuation Method}

Policymakers are often interested in how the public values goods and services that are not traded in the marketplace. These values can be estimated using contingent valuation (CV) methods, in which survey questions elicit respondents' willingness to pay (Michell and Carson, 1989; Carson and Hanemann, 2005; Alberini and Kahn, 2006).

The litigation surrounding the 1989 Exxon Valdez disaster led both the state of Alaska and Exxon to conduct CV studies of the damaged environmental assets and to assess the accuracy and usefulness of CV studies in general. Around that time, the National Oceanic and Atmospheric Administration (NOAA) appointed an expert panel that included the Nobel-Prize winning economists Kenneth Arrow and Robert Solow and charged it with studying whether CV methods can provide reliable information about passive-use values.

The NOAA panel concluded that CV methods can generate useful information (Arrow et al., 1993) and issued the following recommendations to maximize the reliability of CV estimates: 1) Use of a probability sample; 2) using face-to-face or telephone interviews but not mail surveys; 3) measuring willingness to pay rather than willingness to accept ${ }^{7}$; 4) pretesting of the CV questionnaire; 5) phrasing CV questions in the form of hypothetical referenda in which respondents are told how much they would

\footnotetext{
${ }^{7}$ Willingness to pay refers to how much a person would pay to reduce something that causes disutility. Willingness to accept refers to how much the person would have to receive to compensate them for an increase in something that causes disutility. The two tend not to be equal because of the "endowment effect”; see Hanemann (1991).
} 
have to pay in increased taxes if the measure passed and are then asked to cast a simple yes or no vote; 6) providing a "would not vote" option in addition to the "yes" and "no" vote options on the referendum; 7) breaking down willingness-to-pay by a variety of respondent characteristics such as income, interest, and attitudes; 8) reminding respondents of their actual budget constraint when considering their willingness to pay. The survey questions designed for this paper adhered to each of these recommendations. In recent years, CV has been increasingly applied to topics in health economics (Donaldson, Mason, and Shackley, 2006; Smith 2003; Olsen and Smith, 2001). In particular, several recent papers apply the CV method to obesity, estimating willingness to pay for obesity treatment (Narbro and Sjostrom 2000), community-based weight loss programs (Roux et al. 2004), bariatric surgery (Finkelstein et al. 2005), and smoking cessation treatment that does not result in weight gain (Busch et al. 2004). This paper complements this previous literature in that while others estimated willingness to pay for treatment of own obesity, this paper estimates adults' willingness to pay to reduce childhood obesity. Moreover, rather than valuing a medical procedure, this paper estimates the willingness to pay for a public policy, which can be interpreted as a measure of support for the policy.

This paper uses the double-bounded CV model, in which survey respondents are asked a sequence of questions that progressively narrows down the willingness to pay, because this method has been shown to generate more efficient estimates than those based on a single question (Hanemann, Loomis, and Kanninen, 1991). This method is generally preferred to asking an open-ended question about willingness to pay (Watson and Ryan 2007). For example, researchers found that people commonly gave "protest 
answers” to open-ended questions, responding with zeros or extremely high values (Haab and McConnell, 2002). Asking simple yes/no questions eases the burden on the respondent, decreasing the number of protest answers, and the "would not vote" option allows protest answers to be submitted without introducing bias in estimates of WTP. However, there are also limitations of the double-bounded CV model; for example, respondents may become indignant because they believe that they struck a deal with their response to the first question but now are being asked a follow-up question with a different amount, or may feel guilty at having said no to the first question and therefore may be more likely to say yes to the second (smaller) amount (Watson and Ryan, 2007).

We assume that each person $i$ has a willingness to pay for reductions in childhood obesity that is equal to $Y_{i}^{*}$ and is related to the person's characteristics $X_{i}$ in the following way: $Y_{i}^{*}=X_{i} \beta+\varepsilon_{i}$ where $\varepsilon_{i}$ is assumed to be mean zero and normally distributed. We do not observe $Y_{i}^{*}$ but we know that the willingness to pay of person $i$ lies in the interval [ $Y_{i}$, $Y_{i 2}$ ] because of the responses they gave to a series of CV questions. Therefore, the likelihood contribution of the individual is $\operatorname{Pr}\left(Y_{i 1} \leq Y_{i}^{*} \leq Y_{i 2}\right)$ or $\operatorname{Pr}\left(Y_{i 1} \leq X_{i} \beta+\varepsilon_{i} \leq Y_{i 2}\right)$. For left-censored data (for which a lower bound is not known), the likelihood contribution is $\operatorname{Pr}\left(X_{i} \beta+\varepsilon_{i} \leq Y_{i 2}\right)$ and for right-censored data (for which an upper bound is not known) it is $\operatorname{Pr}\left(Y_{i 1} \leq X_{i} \beta+\varepsilon_{i}\right)$. The maximum likelihood function is estimated using the interval regression command intreg in STATA 10. Whereas a probit regression estimates the probability that a latent variable exceeds a certain threshold, the interval regression estimates the probability that a latent variable exceeds one threshold but is less than another threshold; i.e., it estimates the probability of the latent variable lying in a 
certain interval (StataCorp 2007). The regression results are used to estimate individual WTP; both the mean and median are reported. Bootstrap standard errors (200 replications) are used to calculate the $95 \%$ confidence interval on the mean and median WTP.

\section{Data: Empire State Poll (ESP)}

The questions regarding willingness to pay for policies to reduce childhood obesity were included in the 2006 Empire State Poll (ESP). The Empire State Poll is a survey of adults (aged 18 and over) who live in New York State that is conducted annually by the Survey Research Institute at Cornell University.

The ESP sample consists of randomly selected households generated by random digit dial (RDD) sampling of all telephone exchanges within New York State and includes all listed and unlisted households. Households from black or Hispanic neighborhoods were somewhat over-sampled to ensure their proper representation in the final sample. After a household was selected, a household member who was at least 18 years old was randomly selected from within the household based on who has the most recent birthday. All respondents had to be residents of New York State. This selection procedure ensures that every household with a telephone has an equal chance of being included in the survey; and once a household is selected, each adult in the household has an equal chance of being chosen for the interview. Full details of the polling methodology can be found in Nisbet (2006).

Telephone surveys took place between February 2, 2006 and March 19, 2006. All interviews were conducted using a Computer Assisted Telephone Interviewing (CATI) 
software system. The 2006 Empire State poll had 800 respondents, which implies that there is only a $5 \%$ chance that random variations in the sample cause the results to vary by more than 3.5 percentage points (Nisbet 2006).

The cooperation rate (total number of survey completions divided by the number of potential interviews which implies contact was made with a properly selected respondent) for the ESP 2006 was 62.2\%, and the American Association of Public Opinion Research definition of response rate (total number of survey completions divided by the total eligible sample) was $25.2 \%{ }^{8}$ These cooperation and response rates are consistent with those of other recent surveys of New York State residents including those by CBS News and the Pew Research Organization (Nisbet 2006). ${ }^{9}$

Survey response rates, particularly those for random-digit dialing surveys like the ESP, fell during the 1990s (Biener et al., 2004). This is of potential concern, because if the non-respondents differ in important ways from respondents then survey results may be biased. To investigate the impact of increased non-response on survey results, two recent papers altered response rates by changing the number of repeat attempts at contact (one experimentally ex ante and another ex post using call-record histories), and both found little effect of increased non-response on estimates of consumer sentiment (Curtin et al., 2000) or a wide range of other topics commonly covered in surveys (Keeter et al., 2000). A comparison of surveys of smoking prevalence over time also found no

\footnotetext{
${ }^{8}$ For each survey, the American Association for Public Opinion Research recommends reporting a host of response rates, cooperation rates, refusal rates, and contact rates, the definitions of which can be found in that organization's Standard Definitions (AAPOR, 2000). For the ESP 2006, response rates 1 and 2 were both $23.5 \%$, and response rates 3 and 4 were both $25.2 \%$. Cooperation rates 1 and 2 were both $58.7 \%$, and cooperation rates 3 and 4 were both $62.2 \%$. Refusal rate 1 was $14.3 \%$, refusal rate 2 was $15.3 \%$, and refusal rate 3 was $17.2 \%$. Contact rate 1 was $40.0 \%$, contact rate 2 was $42.9 \%$, and contact rate 3 was $48.2 \%$.

${ }^{9}$ If the ESP did not randomly choose respondents within households and did not utilize unlisted phone numbers it would likely have a higher contact rate and therefore response rate, although also a less representative sample (Langer 2003).
} 
evidence that increased non-response affected the representation of population subgroups (Biener et al., 2004). Langer (2003) reviews recent research and concludes there is "no substantial effect of lower response rates on measurements of opinion.” (Langer 2003, p. 17).

The random digit dial of the ESP includes cell phones, but cell phone users tend to not to participate in phone surveys because it costs them air time. A Pew Research Center study found that the rise in the percentage of Americans with only a cell phone (which the Center estimates to be $14 \%$ of the public) has a "minimal" impact on survey results (Pew Research Center, 2008, 2006; 1).

ESP 2006 sample weights are used in each regression so that results are generalizable to all New York State residents. The willingness to pay of a state's population is of interest because virtually all state legislatures are considering enacting policies to reduce childhood obesity (Cawley and Liu 2008). It is a strength that this study utilizes a sample that is representative of a state population. Many CV studies use samples of convenience, producing results that cannot be easily generalized.

The ESP collects a host of demographic, labor market, and other variables. In addition, each respondent to the ESP 2006 was asked a series of three CV questions to ascertain their willingness to pay to reduce childhood obesity. Prior to the 2006 ESP, the Survey Research Institute conducted a pretest of the CV questions; based on the responses the CV questions were revised (see Appendix for details). In its final form on the ESP 2006, the opening CV question read:

Suppose there is a new voter referendum in your town. The referendum will enact policies that will reduce youth obesity in your town by $50 \%$ (set aside for now how it will reduce youth obesity, but assume it will do so with certainty). If the referendum passes, 
you and everyone else will have to pay \$Y more in taxes every year. Given your current budget, would you vote for or against this referendum?

_ FOR _ AGAINST _ WOULD NOT VOTE

This question adheres to each of the NOAA expert panel recommendations: 1) It is asked of a probability sample; 2) it is asked through a telephone interview, not a mail survey; 3) it measures willingness to pay rather than willingness to accept; 4) the CV questions were pre-tested and revised in light of feedback; 5) the CV questions were phrased in the form of hypothetical referenda in which respondents are told how much they would have to pay in increased taxes if the measure passed and are then asked to cast a simple yes or no vote; 6) a "would not vote" option is provided; 7) later in this paper we break down estimated willingness-to-pay by a variety of respondent characteristics such as income, interest, and attitudes; 8) respondents are reminded to consider their actual budget when deciding their willingness to pay.

The magnitude of the reduction (50\%) was selected based on the magnitude of the increase in childhood obesity in recent years; since 1970, the fraction overweight has almost quadrupled among children aged 6-11 years (Ogden et al., 2002). In effect, a 50\% reduction from current levels of obesity would eliminate half of that recent rise (i.e. childhood obesity would have doubled instead of quadrupled since 1970). One might be concerned that the $50 \%$ rise would seem implausible to the respondent, but the magnitude of change we ask people to value is half of that the respondent has observed since 1970 . In the context of a 300\% increase in (i.e., a quadrupling of) childhood obesity, a 50\% change is not unimaginable. Responses to an open-ended question that asked respondents to explain their answers to the CV questions yielded no evidence that respondents were concerned about, or distracted by, the magnitude of the reduction in 
childhood obesity that they were asked to consider (the responses to the open-ended question, which span 22 pages, are available upon request). These open-ended answers reveal that overwhelming majority of people did not dismiss the question as implausible or hard to imagine but based on their answers on a weighing of the costs and benefits of the referendum.

No specific method of achieving the reduction was specified is because to specify an arbitrary policy risked leading respondents to focus on the expected effectiveness of the specific policy than on weighing the specified costs and benefits. The goal of this paper is to determine how respondents value reductions in childhood obesity, not how they value a specific anti-obesity policy. Responses to the open-ended question that asked respondents to explain their answers to the CV questions yielded no evidence that respondents were concerned or distracted by the lack of a specific policy to achieve the 50 percent reduction in childhood obesity (available upon request).

In the first of the series of $\mathrm{CV}$ questions, the value of $\$ \mathrm{Y}$ was $\$ 50 .{ }^{10}$ If respondents answered that they would vote against the referendum, they were asked a follow-up question in which they were asked how they would vote if their taxes would instead rise by a lesser amount. Respondents who answered that they would vote for the referendum were asked in a follow-up question how they would vote if their taxes would instead rise by a higher amount. A second follow-up question (the third question in the series) further narrowed down the respondents' willingness to pay. Based on their responses to these three questions, respondents ended up in one of the following

\footnotetext{
${ }^{10}$ Dollar values in the DBDC questions were based on the two surveys that asked about respondents' support for tax hikes to reduce obesity (Lane, Snell, Perry \& Associates 2003; Lee and Oliver 2005). They were then modified in response to the pre-test by the Survey Research Center.
} 
categories of willingness-to-pay in dollars: $<10,(10,25),(25,40),(40,50),(50,75),(75$, 100), (100, 200), > 200; see Figure $1 .{ }^{11}$

The regressors in the interval regressions include: number of children in the household and indicator variables for white (omitted category is nonwhite), female (omitted category male) household income over $\$ 50,000$ (omitted category is household income less than $\$ 50,000$ ), and whether respondent is obese. ${ }^{12}$ Respondents are asked to value a proportional (50\%) reduction in childhood obesity; those who perceive that obesity is a bigger problem are likely to assign a greater value to that reduction. For this reason the set of regressors includes proxies for the respondent's perception of obesity: 1) an indicator for whether the respondent said they believe youth obesity in the U.S. is a major problem (the omitted category is stating that youth obesity is either a minor problem or not a problem at all); 2) indicators for whether the respondent thinks youth obesity is among the most important or least important problems facing American youth (the omitted category is "somewhere in the middle"); 3) indicators for whether the respondent said that, of a fixed budget to spend on combating public health problems facing American youth, youth obesity should receive a greater than even share or less than even share (the omitted category is an even share relative to other public health problems); and 4) indicators for whether the respondent thinks obesity is primarily due to individual choices or genetics (the omitted category is thinking obesity is primarily due to environment).

\footnotetext{
${ }^{11}$ One could instead define the absolute lower bound as zero, but this would rule out the possibility that some respondents could be so opposed to the policy that they would have to be paid (in the form of a tax cut) in order to support the policy.

${ }^{12}$ Weight and height are self-reported in the Empire State Poll, so we correct for reporting error in these variables using validation data from the National Health and Nutrition Examination Survey III; see Cawley and Burkhauser (2006).
} 
Political beliefs are also relevant because they relate to preferences for taxes, public goods, and government intervention. The regressors that proxy for the respondent's general political beliefs include: 1) an indicator variable for whether the respondent rated the tax situation in New York State as poor (the omitted category is rating it fair, good, or excellent); 2) an indicator variable for whether the respondent selfidentified as liberal, and another for whether respondent self-identified as a conservative (the omitted category is "middle of the road”); 3) indicator variables for whether the respondent self-identified as a Democrat or a Republican (the omitted category is independent of the two major parties). In the base model, all of these variables are included as regressors. However, there may be collinearity between these different measures, so alternate models are estimated including just one of these proxies at a time among the regressors. Table 2 provides summary statistics for the regression sample used in this paper.

\section{Empirical Results}

Figure 1 shows the percentage of respondents whose willingness to pay lies within each bounds. The mode (36\% of respondents) is the lowest category (willing to pay less than $\$ 10$ per year) and the next largest group of respondents (15.9\%) is in the highest category (willing to pay at least $\$ 200$ a year).

Interval regression results are presented in Table 3 (which is split in half for ease of reading); each model varies in terms of which proxies for support for anti-obesity policies or political affiliation or philosophy are included. These tables list coefficients, elasticities (for coefficients that are statistically significant in any model presented in the 
table), and standard errors in parentheses. Statistical significance is indicated using asterisks. Table 3 column 1 lists results for the baseline model that includes the full set of regressors. Based on the results of the baseline model, the mean estimated willingness to pay for a $50 \%$ reduction in youth obesity is $\$ 46.41$; bootstrap standard errors yield a $95 \%$ confidence interval of (\$33.45, \$59.15). The median willingness to pay is $\$ 32.66$ (95\% confidence interval: \$17.66, \$47.65).

Because the CV questions are hypothetical it is reasonable to ask whether respondents are giving random answers to get through the survey faster. The NOAA committee offered two suggestions to address this issue. First, include as an optional answer "Would not vote", so people can speed through the survey if they wish without generating nonsensical WTP (in this study, 0.3 to 2.8 percent of the sample stated they would not vote). Second, the NOAA committee recommended that researchers investigate the face validity of the responses. In the present context, that involves testing whether willingness to pay for reductions in youth obesity varies in logical ways with observed characteristics, such as household income, opinion of current tax levels, and perception of whether youth obesity is a major problem.

The results in Table 3 indicate that WTP varies in logical ways with observables ${ }^{13}$ and therefore has considerable face validity. One might expect that, if such policies are normal goods, higher-income people would demand more of them. This is confirmed in column 1: a household income over $\$ 50,000$ per year is associated with a $39 \%$ higher willingness to pay. Those who perceive obesity is a major problem are estimated to have

\footnotetext{
${ }^{13}$ These same variables are statistically significant if the natural log of the bound rather than the bound in dollar terms is used to estimate the interval regression. I am not able to compare the mean and median WTP in each case because of the retransformation issues involved in using the log bound in the interval regression.
} 
an $86 \%$ higher willingness to pay. Those who think obesity is among the most important problems facing American youth are willing to pay $18 \%$ more while those who think it is among the least of the problems facing American youth are willing to pay $32 \%$ less. Those who report that a greater-than-even share of the public health budget should be devoted to youth obesity as opposed to other youth health concerns have 35\% higher WTP. Those who think the tax situation in New York State is poor are willing to pay $35 \%$ less. Self-described liberals are willing to pay 20\% more, and Democrats have $32 \%$ higher WTP. In summary, WTP is generally correlated in expected ways with observable characteristics such as income, perception of obesity, and perception of tax burden, and political persuasion.

Subsequent columns of Table 3 provide results for more parsimonious models that include only one of the proxies for support for anti-obesity policies. Because the proxies tend to be correlated, the magnitude of the elasticities tends to rise in the more parsimonious models. For example, perceiving obesity to be a major problem is associated with 86\% higher WTP in the base model (column 1) but 200\% higher WTP in a more parsimonious model (column 3). In particular, the magnitude of the results for political persuasion change considerably because party affiliation (e.g. Democrat, Republican) is highly correlated with political philosophy (e.g. liberal, conservative). In a parsimonious model (column 9), Democrats have a 26\% higher, and Republicans have an 18\% lower, WTP. Another change in the more parsimonious model is that both people who think obesity is due to individual choices and people who think obesity is due to genetics have significantly lower WTP relative to people who think obesity is primarily due to the environment (column 6). 


\section{Discussion}

The rise in childhood obesity has led governments to consider a variety of policy responses (Cawley and Liu 2008). The critical information needed to guide these decisions include: 1) what policies are effective and cost-effective; and 2) how much are taxpayers willing to pay for these programs? Information on the cost-effectiveness of anti-obesity programs is collected elsewhere (CDC 2008; Cawley 2007). This study provides the other critical information: how much taxpayers are willing to pay for policies to reduce childhood obesity.

The WTP data collected have considerable face validity; a higher willingness to pay for reductions in childhood obesity is reported, on average, by those who have higher household income, perceive childhood obesity as a major problem, and self-identify as liberal or a Democrat. Lower willingness to pay is reported, on average, by those who think childhood obesity is one of the least important problems facing American youth, who disapprove of their current tax burden, and who self-identify as Republican. The association of party affiliation with WTP for reductions in childhood obesity is consistent with the finding that enactment of a law to reduce childhood obesity is $20 \%$ more likely in states headed by a Democratic governor and that enactment of a school nutrition law is 19.4\% less likely in states with a Republican-controlled legislature (Cawley and Liu 2008). The results also suggest that public health advocates might achieve greater success by targeting their legislative initiatives to localities or states in which the median voter is liberal or Democrat. 
The median voter model theorem implies that, under certain conditions, the outcome of majority voting is that expenditures will equal those preferred by the median voter (Arrow 1951). The estimates of this paper imply that, in New York State, the median willingness to pay for a 50\% reduction in childhood obesity is \$32.66 (95\% confidence interval: \$17.66, \$47.65) per year.

Two published surveys found that substantial percentages of American reported that they were willing to pay higher taxes for policies to reduce childhood obesity. Their questions are not directly comparable to the CV questions in this paper, in part because neither previous survey explicitly stated the benefit of the policy in terms of a specific reduction in childhood obesity. However, even if respondents interpreted both proposed policies as generating a 50\% reduction in childhood obesity, the results of this paper still imply a lower WTP than that found by either previous study. While the Harvard Forums on Health poll found that $42 \%$ said they would pay more than $\$ 100$ a year in taxes to reduce childhood obesity (Lane, Snell, Perry \& Associates, 2003), in the ESP 2006 only 29\% reported a WTP in that range. Lee and Oliver (2005) find that $64 \%$ were willing to pay \$50 or more a year (for more nutritious school lunches), whereas in the ESP 2006 only $45.7 \%$ had a WTP in that range. To the extent that respondents to the previous surveys were expecting less than a 50\% reduction in youth obesity as a result of these proposed policies (which seems likely), the gap between the WTP found by this paper and those implied by earlier papers widens further. While caution must be used when making comparisons across samples and survey questions, these discrepancies suggest that using simple survey questions may seriously overstate taxpayer support for antiobesity policies. 
Despite the fact that the WTP found in this paper are somewhat less than that implied by earlier surveys, the aggregate WTP is substantial. The mean WTP in this study was $\$ 46.41$ (95\% CI: $\$ 33.45, \$ 59.15)$. Many CV surveys are administered to convenience samples, so it is a strength of this paper that the data, from the Empire State Poll of New York, generalize to the entire state of New York. The results of this paper imply a total WTP by New York State adult residents of $\$ 690.6$ million per year (95\% CI: $\$ 497.7, \$ 880.2$ ) for a $50 \%$ reduction in youth obesity.

A limitation of this study is that it could not be conducted with nationally representative data. It is not clear whether the mean and median WTP estimates for New York State residents are higher or lower than those for Americans as a whole. On the one hand, New York State residents are heavily taxed and therefore at the margin may be less willing to pay for any public policies than residents of other states. On the other hand, New York State is also relatively liberal and may have, unconditionally, stronger preferences for these types of policies. Keeping all of these caveats in mind, if for the sake of argument the WTP estimate was applied to the entire U.S. it implies a national WTP of $\$ 10.6$ billion (95\% CI: \$7.6, \$13.5). ${ }^{14}$

Natural comparisons for these total WTP are the current spending by the New York State and U.S. Federal governments on anti-obesity policies, but such estimates do not exist. ${ }^{15}$ However, these aggregate WTP estimates are clearly far in excess of what is

\footnotetext{
${ }^{14}$ If the mean WTP is interpreted as the WTP of the entire household rather than just the respondent, then the total WTP by all New York State households is estimated to be $\$ 327.7$ million per year, and the total WTP by all U.S. households is estimated to be $\$ 4.8$ billion.

${ }^{15}$ While the total amount spent on all anti-obesity programs is not known, it is straightforward to find the budgets for specific programs. For example, the U.S. government spent $\$ 340$ million over five years - the most that Congress ever appropriated to the Centers for Disease Control and Prevention (CDC) for a single initiative - on the marketing campaign VERB: It's What You Do (Collins and Wechsler 2008; Wong et al. 2008). (Berkowitz et al. (2008) and Bauman et al. (2008) provide evidence that the VERB campaign increased youth physical activity.) A more typical budget is the $\$ 1$ million spent by the National Cancer
} 
currently being spent; for example, federal spending on all public health (all age groups, all public health challenges) through the CDC in 2005 was \$20.99 per capita (IOM 2007), which equals $\$ 6.2$ billion.

A related question is whether there are effective programs on which to spend tax dollars. Two school-based interventions have been shown to be cost-effective at preventing childhood obesity by focusing on improving nutrition and increasing physical activity: Planet Health (Wang et al. 2003) and the Coordinated Approach to Child Health or CATCH (Brown et al. 2007). However, many other candidate interventions lack evidence of efficacy or cost-effectiveness (Cawley 2007) so policymakers should be wary of misallocating resources.

One might wonder why respondents are willing to pay anything at all to reduce childhood obesity. Suggestive evidence on this question comes from an open-ended question asked of all respondents after the final CV question: "Please explain why you would vote for (against) the referendum in this case.” Answers indicate that to some extent, people perceive benefits to their own children. The answers of others indicate altruism, e.g.: "I think it is for the public good." Others state that it may be cheaper to address it today than pay higher insurance or medical costs tomorrow.

Given the motivation of some respondents of avoiding external costs, we next compare the total WTP of New Yorkers for reductions in childhood obesity to the expected savings that would result from the reduction in childhood obesity due to lower external costs imposed through public health insurance (Medicaid and the State Children's Health Insurance Program or SCHIP) or private group health insurance. If

Institute for its 5-A-Day Educational Campaign to increase fruit and vegetable consumption (IOM 2007). The Fresh Program, which supplies fresh fruit and vegetables to schools to improve the quality of school meals, received \$50 million in Federal funding in 2005 (IOM 2007). 
New Yorkers are well-informed about the external costs of childhood obesity, then we should find that the total WTP for obesity reductions is at least as high as the external cost savings that would result. The external costs of childhood obesity can be decomposed into two categories: the external costs imposed during childhood, and those imposed during adulthood. We consider each of these in turn.

We first calculate the external costs associated with obese children today. Johnson, McInnes, and Shinogle (2006) calculate that each overweight child each year causes \$12.09 (in 1998 dollars) in additional health care expenditures; adjusted to May 2006 dollars it equals $\$ 15.11$. I assume that all of these additional costs represent externalities imposed on the public through public health insurance programs like Medicaid and the State Children's Health Insurance Program or through private group health insurance (no group health insurance adjusts premiums to reflect the clinical weight classification of covered minors).

We next multiply the $\$ 15.11$ per-overweight-child external cost by the number of overweight children in New York State. The U.S. Census estimates that New York was home to 4.5 million youths under the age of 18 in the year 2005, and the CDC reports that $11 \%$ of New York State high school students were clinically overweight in 2005 (CDC, 2006). Assuming that the prevalence of overweight among high school students was the same among younger youths, the total number of overweight New York State youths is roughly 495,000. Multiplying the number of overweight New York youths by the $\$ 15.11$ in additional health care costs for each overweight youth generates an external cost of childhood obesity in New York State of \$7.5 million. The CV question asked about 
reducing childhood obesity by half, so the associated savings would presumably be half the total external costs, or \$3.8 million.

We next consider the savings associated with decreased adult obesity in the future. An important statistic for this calculation is the percentage of adult obesity that can be attributed to childhood obesity (the Population Attributable Risk); in the literature review by Serdula et al. (1993) the average published estimate is $13.0 \%$. We assume that if childhood obesity fell by half, adult obesity would fall by $6.5 \%$ (half of $13.0 \%$ ) in the long run. Finkelstein et al. (2004) estimate that the total external costs of adult obesity in New York State in 2003 were $\$ 4.93$ billion in 2003 dollars (which includes costs to both Medicaid and Medicare). In 2006 dollars this equals $\$ 5.426$ billion. (Clearly, the consequences of obesity for health expenditures are much greater for adults than children.) A 6.5\% reduction in adult obesity is expected to save 6.5\% of that amount, or $\$ 352.7$ million. However, a 6.5\% reduction in adult obesity will not occur immediately; that is the long-run reduction after today's youth have matured through the age distribution. As a result, the value today of these future savings is far less than $\$ 352.7$ million. Moreover, we acknowledge that projections of savings in future decades are likely to be highly inaccurate because of future changes in costs and technology.

These estimates of savings from external costs help put in context the willingness of New York State residents to pay for reductions in childhood obesity. Although the savings today from reducing childhood obesity by half is estimated to be $\$ 3.8$ million per year, New Yorkers are willing to pay $\$ 690.6$ million per year for such a reduction. Even when one adds in the undiscounted savings from decreased external costs associated with 
less adult obesity in the future, the annual savings total \$356.5 million, still far less than New Yorkers’ WTP.

Limitations of this paper include that variation in responses may be driven in part by different estimates of the baseline prevalence of childhood obesity. To some extent these differences are controlled for using the regressors that reflect the respondent's opinion of whether childhood obesity is a major problem, among the most important health problems facing youth today, and the extent to which reducing childhood obesity should be a budget priority.

Another limitation of $\mathrm{CV}$ in general is the possibility of protest bids introducing bias. To minimize such bias the ex ante approach of this paper is to ask DBDC questions instead of open-ended questions that could result in excess zeros or implausibly large responses (Haddad and Howarth 2006). ${ }^{16}$ In addition, this paper used another recommended strategy to decrease such bias (Arrow 1993): allowing respondents to state "would not vote". The percentage of respondents taking that option ranged from 0.3 to 2.8 percent. These respondents were dropped from the sample. ${ }^{17}$ What is unknowable is the percentage of respondents who voted but in a way inconsistent with their true valuation. Research on CV methodology has not resolved how extensive this problem is and whether it has a systematic directional bias (Boyle 2004).

We also acknowledge limitations of the double-bounded CV model. While it is generally perceived to be preferable to a single-question CV model (Hanemann, Loomis, and Kanninen, 1991; Haab and McConnell, 2002), asking follow-up questions could

\footnotetext{
${ }^{16}$ Another strategy for minimizing such bias that was not used in this survey is to use a "cheap talk design" - explicitly raise the issue of such bias with the respondent (Cummings and Taylor 1999).

${ }^{17}$ There is no well-established theoretical basis for dropping nonresponses and others impute the value of non-answers but this is considered dangerous because it yields a dataset that does not include the same variability that would be found in a complete dataset (Haddad and Howarth 2006).
} 
introduce bias by provoking indignation or guilt (Watson and Ryan, 2007). Despite these limitations, this paper provides insights into voter preferences for anti-obesity policies and associated tax increases and, therefore, useful information for advocates and policymakers. 


\section{Works Cited}

Alberini, Anna, and James R. Kahn (eds.). 2006. Handbook on Contingent Valuation. (Northampton MA: Edward Elgar).

American Association for Public Opinion Research. 2000. Standard Definitions: Final Dispositions of Case Codes and Outcome Rates for Surveys. (Lenexa, Kansas: The American Association for Public Opinion Research).

Arrow, Kenneth, Robert Solow, Paul R. Portney, Edward E. Leamer, Roy Radner, and Howard Schuman. 1993. "Report of the NOAA Panel on Contingent Valuation."

Arrow, Kenneth. 1951. Social Choice and Individual Values. (New Haven: Yale University Press).

Bauman, Adrian, Heather R. Bowles, Marian Huhman, Carrie D. Heitzler, Neville Owen, Ben J. Smith, Bill Reger-Nash. 2008. “Testing a Hierarchy-of-Effects Model: Pathways from Awareness to Outcomes in the VERB ${ }^{\mathrm{TM}}$ Campaign 2002-2003.” American Journal of Preventive Medicine, 34(6 Supplement 1): S249-S256.

Berkowitz, Judy M., Marian Huhman, Mary Jo Nolin. 2008. "Did Augmenting the VERB $^{\text {TM }}$ Campaign Advertising in Select Communities Have an Effect on Awareness, Attitudes, and Physical Activity?” American Journal of Preventive Medicine, 34(6 Supplement 1): S257-S266.

Biener, Lois, Catherine A. Garrett, Elizabeth A. Gilpin, Anthony M. Roman, and Douglas B. Currivan. 2004. "Consequences of Declining Survey Response Rates for Smoking Prevalence Estimates.” American Journal of Preventive Medicine, 27(3): 254-257.

Boyle, Kevin J. 2004. “Contingent Valuation in Practice.” Chapter 5 in: A Primer on Nonmarket Valuation, edited by Patricia A. Champ, Kevin J. Boyle, and Thomas C. Brown. (Boston MA: Kluwer Academic Publishers).

Brown, Henry Shelton III, Adriana Perez, Yen-Peng Li, Deanna M. Hoelscher, Steven H. Kelder, and Roberto Rivera. 2007. International Journal of Behavioral Nutrition and Physical Activity, 4:47.

Busch, Susan H., Tracy A. Falba, Noelia Duchovny, Mireia Jofre-Bonet, Stephanie S. O’Malley, and Jody L. Sindelar. 2004. "Value to Smokers of Improved Cessation Products: Evidence From a Willingness-to-Pay Survey.” Nicotine \& Tobacco Research, 6(4): 631-639.

Carson, Richard T. and W. Michael Hanemann. 2005. “Contingent Valuation” Chapter 17 in Handbook of Environmental Economics, Volume 2, edited by Karl-Goran Maler and Jeffrey R. Vincent. (New York: Elsever North-Holland).

Cawley, John. 2007. "The Cost Effectiveness of Programs to Prevent or Reduce Obesity: The State of the Literature and a Future Research Agenda.” Archives of Pediatrics \& Adolescent Medicine, 161(6): 611-614.

Cawley, John, and Richard V. Burkhauser. 2006. "Beyond BMI: The Value of More Accurate Measures of Fatness and Obesity in Social Science Research.” National Bureau of Economic Research Working Paper \# 12291.

Cawley, John, and Feng Liu. 2008. "Correlates of State Legislative Action to Prevent Childhood Obesity.” Obesity, 16(1): 162-167. 
Centers for Disease Control and Prevention. 2006. “The Obesity Epidemic and New York Students.” World wide web content: http://www.cdc.gov/HealthyYouth/overweight/pdf/NewYork.pdf

Centers for Disease Control and Prevention. 2008. Guide to Community Preventive Services. World wide web content: http://www.thecommunityguide.org/ Accessed February 8, 2008.

Collins, Janet L. and Howell Wechsler. 2008. “The VERB Campaign.” American Journal of Preventive Medicine, 34(6 Supplement 1): S171-S172.

Cummings, Ronald G. and Laura O. Taylor. 1999. "Unbiased Value Estimates for Environmental Goods: A Cheap Talk Design for the Contingent Valuation Method.” American Economic Review, 89(3): 649-665.

Curtin, Richard, Stanley Presser, and Eleanor Singer. "The Effects of Response Rate Changes on the Index of Consumer Sentiment.” Public Opinion Quarterly, 64: 413-428.

Donaldson, Cam, Helen Mason, and Phil Shackley. 2006. "Contingent Valuation in Health Care.” In The Elgar Companion to Health Economics, Andrew M. Jones (editor). (Northampton, MA: Edward Elgar).

Evans, W. Douglas, Jeanette M. Renaud, Eric Finkelstein, Douglas B. Kamerow, and Derek S. Brown. 2006. "Changing Perceptions of the Childhood Obesity Epidemic.” American Journal of Health Behavior, 30(2): 167-176.

Evans, W. Douglas, Eric A. Finkelstein, Douglas B. Kamerow, and Jeanette M. Renaud. 2005. "Public Perceptions of Childhood Obesity." American Journal of Preventive Medicine, 28(1): 26-32.

Finkelstein, Eric A., Derek S. Brown, Yoav Avidor, and Annie H. Takeuchi. 2005. “The Role of Price, Sociodemographic Factors, and Health in the Demand for Bariatric Surgery.” American Journal of Managed Care, 11(10): 630-637.

Finkelstein, Eric A., Ian C. Fiebelkorn, and Guijing Wang. 2004. "State-Level Estimates of Annual Medical Expenditures Attributable to Obesity.” Obesity Research, 12(1): 18-24.

Gullo, Kelly. 2005. "Most of the American Public, Including a Majority of Parents, Believe that Childhood Obesity in the U.S. Is a Major Problem.” Wall Street Journal Online, 4(3) February 15.

Haab, Timothy C. and Kenneth E. McConnell. 2002. Valuing Environmental and Natural Resources: The Econometrics of Non-Market Valuation. (Northampton MA: Edward Elgar).

Haddad, Brent and Richard Howarth. 2006. "Protest Bids, Commensurability, and Substitution: Contingent Valuation and Ecological Economics.” Chapter 6 in Alberini, Anna, and James R. Kahn (eds.). Handbook on Contingent Valuation. (Northampton MA: Edward Elgar).

Hanemann, Michael, John Loomis, and Barbara Kanninen. 1991. "Statistical Efficiency of Double-Bounded Dichotomous Choice Contingent Valuation.” American Journal of Agricultural Economics, 73: 1255-1263.

Hanemann, W. Michael. 1991. "Willingness to Pay and Willingness to Accept: How Much Can They Differ?” American Economic Review, 81(3): 635-647.

Institute of Medicine. 2005. Preventing Childhood Obesity: Health in the Balance. (National Academies Press: Washington, D.C.). 
Institute of Medicine. 2007. Progress in Preventing Childhood Obesity: How Do We Measure Up? (National Academies Press: Washington, D.C.).

Johnson, Eric, Melayne Morgan McInnes, and Judith A. Shinogle. 2006. "What is the Economic Cost of Overweight Children?” Eastern Economic Journal, 32(1): 171-187.

Keeter, Scott, Carolyn Miller, Andrew Kohut, Robert M. Groves, and Stanley Presser. 2000. "Consequences of Reducing Nonresponse in a National Telephone Survey." Public Opinion Quarterly, 64: 125-148.

Lane Snell Perry \& Associates. 2003. “Obesity as a Public Health Issue: A Look at Solutions.” Press Release.

Langer, Gary. 2003. “About Response Rates: Some Unresolved Questions.” Public Perspective, May/June, pp. 16-18.

Mitchell, Robert Cameron, and Richard T. Carson. 1989. Using Surveys to Value Public Goods: The Contingent Valuation Method. (Washington DC: Resources for the Future).

Narbro, Kristina, and Lars Sjostrom. 2000. "Willingness to Pay for Obesity Treatment.” International Journal of Technology Assessment in Health Care, 16(1): 50-59.

Nisbet, Erik. 2006. "New York Opinion Index. Empire State Poll 2006. Report 1: Introduction and Methodology.” Cornell University Survey Research Institute. World wide web content: http://sri.cornell.edu/sri/files/esp/Report_1_2006_Intro_Method.pdf

Ogden, Cynthia L., Katherine M. Flegal, Margaret D. Carroll, and Clifford L. Johnson. 2002. "Prevalence and Trends in Overweight Among US Children and Adolescents, 1999-2000." Journal of the American Medical Association, 288(14): 1728-1732.

Ogden, Cynthia L., Margaret D. Carroll, Lester R. Curtin, Margaret A. McDowell, Carolyn J. Tabak, and Katherine M. Flegal. 2006. "Prevalence of Overweight and Obesity in the United States, 1999-2004." Journal of the American Medical Association, 295(13): 1594-1555.

Olsen, Jan Abel, and Richard D. Smith. 2001. "Theory Versus Practice: A Review of 'Willingness-to-Pay' in Health and Health Care.” Health Economics, 10:39-52.

Pew Research Center for the People \& The Press. 2008. Ways of Coping with a Growing Population Segment: the Impact of "Cell-Onlys" on Public Opinion Polling.” World wide wbe content. http://peoplepress.org/reports/display.php3?ReportID=391

Pew Research Center for the People \& The Press. 2006. "The Cell Phone Challenge to Survey Research: National Polls Not Undermined by Growing Cell-Only Population.” World wide web content. http://peoplepress.org/reports/display.php3?ReportID=276

Roux, Larissa, Christina Ubach, Cam Donaldson, and Mandy Ryan. 2004. "Valuing the Benefits of Weight Loss Programs: An Application of the Discrete Choice Experiment.” Obesity Research, 12(8): 1342-1351.

San Jose Mercury News / Kaiser Family Foundation. 2004. "Survey on Childhood Obesity: Summary Document and Chartpack.” March. 
Serdula MK, Ivery D, Coates RJ, Freedman DS, Williamson DF, and Byers T. 1993. "Do Obese Children Become Obese Adults? A Review of the Literature." Preventive Medicine, 22(2):167-77.

Smith, Richard D. 2003. "Construction of the Contingent Valuation Market in Health Care: A Critical Assessment.” Health Economics, 12: 609-628.

StataCorp. 2007. Stata Base Reference Manual, Volume 2 I-P Release 10. (Stata Press: College Station TX).

U.S. Department of Health and Human Services. 2000. Healthy People 2010: Understanding and Improving Health, 2nd Edition. Washington D.C.: U.S. Government Printing Office.

U.S. Department of Health and Human Services. 2002. "2000 CDC Growth Charts for the United States: Methods and Development." Vital and National Health Statistics, Series 11, Number 246, May.

Wang, Guijing, and William H. Dietz. 2002. "Economic Burden of Obesity in Youths Aged 6 to 17 Years: 1979-1999.” Pediatrics, 109(5): 81-86.

Wang LY, Yang Q, Lowry R, and Wechsler H. Economic analysis of a school-based obesity prevention program. Obesity Research, 2003; 11(11): 1313-1324.

Wong, Faye L., Michael Greenwell, Suzanne Gates, Judy M. Berkowitz. 2008. "It's What You Do!: Reflections on the VERB ${ }^{\mathrm{TM}}$ Campaign.” American Journal of Preventive Medicine, 34(6 Supplement 1): S175-S182.

Watson, Verity and Mandy Ryan. 2007. "Exploring Preference Anomalies in Double Bounded Contingent Valuation.” Journal of Health Economics, 26: 463-482.

Whitehead, John C. 2006. "A Practitioner's Primer on the Contingent Valuation Method," Chapter 3 in Alberini, Anna, and James R. Kahn (eds.). Handbook on Contingent Valuation. (Northampton MA: Edward Elgar).

Widmeyer Polling \& Research. 2003. Summary of Study Findings: Americans Attitudes on Fighting Obesity.” Press Release. 


\section{Appendix Modifications of Survey Based on Pre-test}

The Empire State Poll conducted a pretest of the CV questions in January 2006; 23 individuals were interviewed. They were administered draft versions of the CV questions and were asked to explain why they responded as they did. The pretest respondents' answers regarding why they would vote for or against the hypothetical referendum in the willingness-to-pay question indicated that they were weighing the costs and benefits of the proposal. Examples:

* I think the $\$ 50$ is too excessive and the $\$ 10$ range I could cope with.

* I am an endocrinologist and I see it all of the time. I think it is a big problem and in the long run it will cost a lot more if we simply let it go.

* We are taxed virtually to death where we live. A little more here and a little more there add up.

* I feel it's each person's own responsibility, so other people shouldn't have to pay.

* It gets out of hand for too much money. We have to put a cap on spending. Based on these responses, respondents appeared to understand the tradeoff they were being asked to consider. A similar open-ended question was included on the main ESP 2006 survey, and the responses again confirmed that respondents appeared to understand the tradeoff they were being asked to consider. A copy of the responses to this openended question is available upon request.

The pretest respondents' answers were used to modify the questionnaire in two ways. First, interviewers reported that respondents were asking how the policies on the referendum would reduce youth obesity. To address this, the question was revised to read in part "(set aside for now how it will reduce youth obesity, but assume it will do so with certainty)". Second, the follow-up CV questions were reworded to clarify that the extra amount will have to be paid every year in higher taxes, which made them consistent with the original question.

An open-ended question that asked respondents to explain their answers to the CV questions was also asked on the actual 2006 Empire State Poll. These answers are also consistent with respondents weighing the costs and benefits of the proposed referendum, and answers frequently refer to either the level of existing taxes, the benefits of preventing childhood obesity, or whether it is appropriate for government to address the problem of childhood obesity. The answers to this open-ended question, which span 22 pages, are available upon request. 
Figure 1: Sequence of Contingent Valuation Questions In Empire State Poll 2006

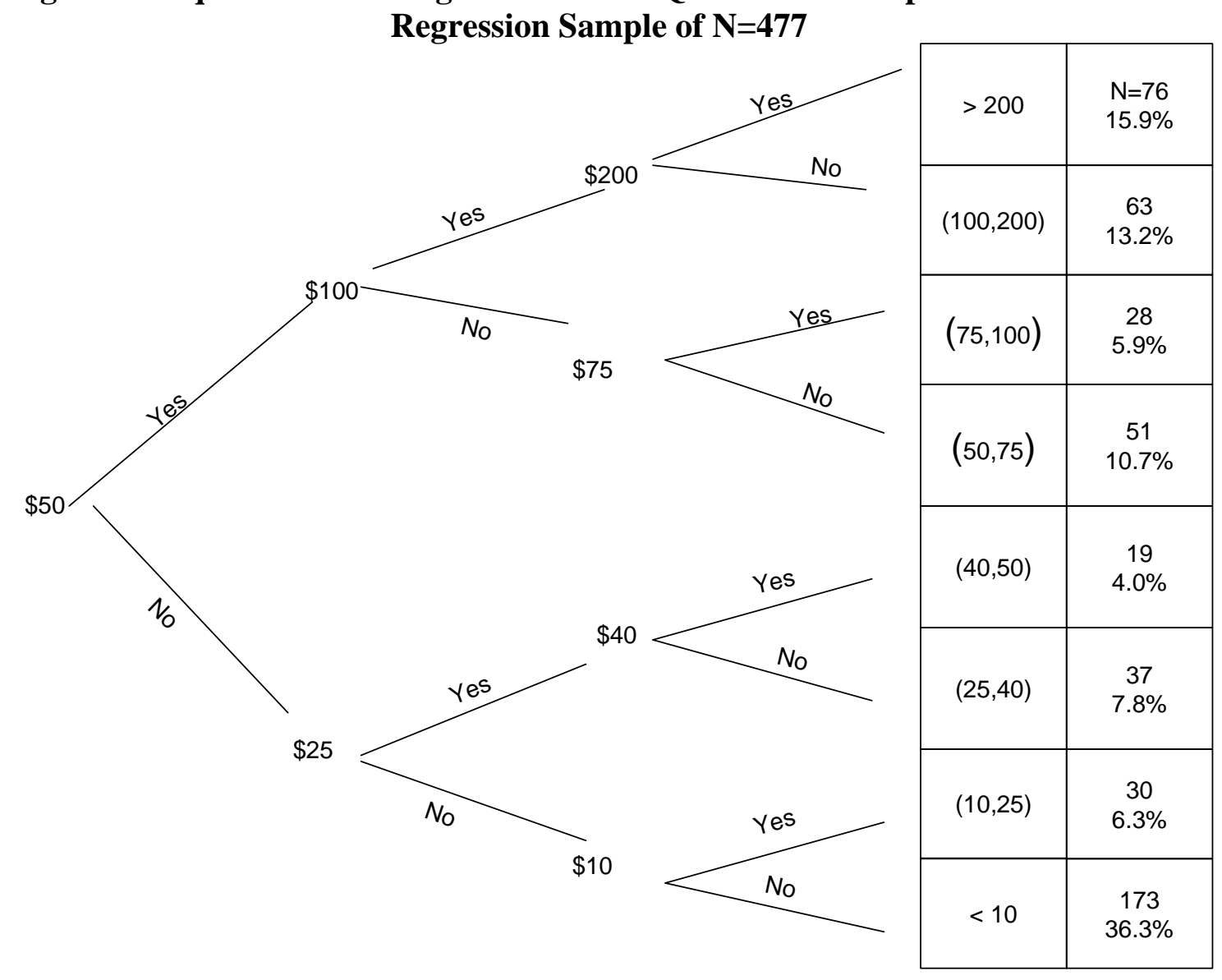

Notes: At each node, respondents were asked whether they would vote for a referendum to enact anti-obesity policies that would reduce childhood obesity by half if as a consequence of passage they would have to pay an additional amount in annual taxes equal to the amount listed at that node. The sequence of three questions gives us bounds on the respondent's willingness to pay for such policies. 
Table 1: Recent Surveys on Significance of Childhood Obesity

\begin{tabular}{|c|c|c|c|c|c|c|c|}
\hline $\begin{array}{c}\text { Study } \\
\text { Number }\end{array}$ & $\begin{array}{l}\text { Researching } \\
\text { Institution }\end{array}$ & Pollster & $\begin{array}{c}\text { Sample } \\
\text { Size }\end{array}$ & $\begin{array}{c}\text { Sample } \\
\text { Representative? }\end{array}$ & $\begin{array}{c}\text { Dates of } \\
\text { Survey }\end{array}$ & Results & Citation \\
\hline 1 & $\begin{array}{l}\text { American Public } \\
\text { Health } \\
\text { Association }\end{array}$ & $\begin{array}{l}\text { Widmeyer Polling \& } \\
\text { Research }\end{array}$ & 600 & Yes - of U.S. & March 2003 & $\begin{array}{l}82 \% \text { concerned about } \\
\text { childhood obesity, and } 89 \% \\
\text { believe it is a serious } \\
\text { problem }\end{array}$ & $\begin{array}{l}\text { Widmeyer } \\
\text { Polling \& } \\
\text { Research (2003) }\end{array}$ \\
\hline 2 & $\begin{array}{l}\text { Harvard Forums } \\
\text { on Health }\end{array}$ & $\begin{array}{l}\text { Lane Snell Perry \& } \\
\text { Associates }\end{array}$ & 1,002 & No & $\begin{array}{l}\text { May-June } \\
2003\end{array}$ & $\begin{array}{l}74 \% \text { believe childhood } \\
\text { obesity is a major problem. }\end{array}$ & $\begin{array}{l}\text { Lane Snell } \\
\text { Perry \& } \\
\text { Associates } \\
\text { (2003) }\end{array}$ \\
\hline 3 & $\begin{array}{l}\text { San Jose Mercury } \\
\text { News/Kaiser } \\
\text { Family } \\
\text { Foundation }\end{array}$ & $\begin{array}{l}\text { International } \\
\text { Communications } \\
\text { Research }\end{array}$ & 1,175 & $\begin{array}{l}\text { Yes - of San } \\
\text { Francisco Bay } \\
\text { Area }\end{array}$ & $\begin{array}{c}\text { Nov - Dec } \\
2003\end{array}$ & $\begin{array}{l}69 \% \text { describe youth obesity } \\
\text { as a major problem and an } \\
\text { additional } 26 \% \text { believe it is } \\
\text { a minor problem }\end{array}$ & $\begin{array}{l}\text { San Jose } \\
\text { Mercury News } \\
(2004)\end{array}$ \\
\hline 4 & $\begin{array}{l}\text { Research Triangle } \\
\text { Institute }\end{array}$ & $\begin{array}{l}\text { Odom Survey Research } \\
\text { Institute at the } \\
\text { University of North } \\
\text { Carolina }\end{array}$ & 1,010 & Yes - of U.S. & $\begin{array}{l}\text { Jan } 17- \\
\text { March 6, } \\
2004\end{array}$ & $\begin{array}{l}41.5 \% \text { perceive childhood } \\
\text { overweight and obesity to } \\
\text { be a very serious problem. }\end{array}$ & $\begin{array}{l}\text { Evans et al., } \\
\text { (2005) }\end{array}$ \\
\hline 5 & $\begin{array}{l}\text { Research Triangle } \\
\text { Institute }\end{array}$ & $\begin{array}{l}\text { Odom Survey Research } \\
\text { Institute at the } \\
\text { University of North } \\
\text { Carolina }\end{array}$ & 1,139 & Yes - of U.S. & $\begin{array}{l}\text { Sept - Oct } \\
2004\end{array}$ & $\begin{array}{l}47.4 \% \text { perceive childhood } \\
\text { overweight and obesity to } \\
\text { be a very serious problem. }\end{array}$ & $\begin{array}{l}\text { Evans et al. } \\
\text { (2006) }\end{array}$ \\
\hline 6 & $\begin{array}{l}\text { Wall Street } \\
\text { Journal }\end{array}$ & Harris Interactive & 2,387 & No & $\begin{array}{l}\text { Feb 4-8, } \\
2005\end{array}$ & $\begin{array}{l}77 \% \text { believe childhood } \\
\text { obesity is a major problem } \\
\text { and an additional } 21 \% \\
\text { believe it is a minor } \\
\text { problem. }\end{array}$ & Gullo (2005) \\
\hline 7 & Cornell University & $\begin{array}{l}\text { ILR Survey Research } \\
\text { Institute at Cornell } \\
\text { University }\end{array}$ & 800 & $\begin{array}{l}\text { Yes - of New } \\
\text { York State }\end{array}$ & $\begin{array}{l}\text { Feb } 2- \\
\text { March 19, } \\
2006\end{array}$ & $\begin{array}{l}83 \% \text { believe youth obesity } \\
\text { is a major problem and an } \\
\text { additional } 13.3 \% \text { believe it } \\
\text { is a minor problem. }\end{array}$ & This paper \\
\hline
\end{tabular}


Table 2: Summary Statistics

Empire State Poll Regression Sample

\begin{tabular}{|c|c|c|c|c|c|}
\hline Variable & $\mathbf{N}$ & Mean & $\begin{array}{l}\text { Standard } \\
\text { Deviation }\end{array}$ & Minimum & Maximum \\
\hline $\begin{array}{l}\text { Lower Bound of Willingness to } \\
\text { Pay }\end{array}$ & 304 & 92.55 & 68.16 & 10 & 200 \\
\hline $\begin{array}{l}\text { Upper Bound of Willingness to } \\
\text { Pay }\end{array}$ & 401 & 60.19 & 66.65 & 10 & 200 \\
\hline Age & 477 & 45.95 & 15.79 & 18 & 88 \\
\hline White & 477 & .77 & 42 & 0 & 1 \\
\hline Female & 477 & .50 & .50 & 0 & 1 \\
\hline Obese & 477 & .28 & .45 & 0 & 1 \\
\hline Number of Kids in Household & 477 & .81 & 1.15 & 0 & 8 \\
\hline Household Income Over $\$ 50,000$ & 477 & .51 & .50 & 0 & 1 \\
\hline $\begin{array}{l}\text { Say Childhood Obesity is a Major } \\
\text { Problem }\end{array}$ & 477 & .81 & .39 & 0 & 1 \\
\hline $\begin{array}{l}\text { Think Youth Obesity Among Most } \\
\text { Important Problems Facing } \\
\text { American Youth }\end{array}$ & 477 & .21 & .41 & 0 & 1 \\
\hline $\begin{array}{l}\text { Think Youth Obesity Among Least } \\
\text { Important Problems Facing } \\
\text { American Youth }\end{array}$ & 477 & .24 & .43 & 0 & 1 \\
\hline $\begin{array}{l}\text { US Should Devote Relatively } \\
\text { Large Share of Public Health } \\
\text { Budget to Obesity }\end{array}$ & 477 & .39 & .49 & 0 & 1 \\
\hline $\begin{array}{l}\text { US Should Devote Relatively } \\
\text { Small Share of Public Health } \\
\text { Budget to Obesity }\end{array}$ & 477 & .40 & .49 & 0 & 1 \\
\hline $\begin{array}{l}\text { Say Obesity Primarily Due to } \\
\text { Individual Choices }\end{array}$ & 477 & .61 & .49 & 0 & 1 \\
\hline $\begin{array}{l}\text { Say Obesity Primarily Due to } \\
\text { Genetics }\end{array}$ & 477 & .14 & .34 & 0 & 1 \\
\hline $\begin{array}{l}\text { Rate Tax Situation in NY State as } \\
\text { Poor }\end{array}$ & 477 & .58 & .49 & 0 & 1 \\
\hline Liberal & 477 & .37 & 48 & 0 & 1 \\
\hline Conservative & 477 & .34 & 48 & 0 & 1 \\
\hline Democrat & 477 & .43 & .50 & 0 & 1 \\
\hline Republican & 477 & .27 & .44 & 0 & 1 \\
\hline
\end{tabular}

Note: if lower bound of willingness to pay is less than $\$ 10$, it is set to missing. Likewise, if upper bound of willingness to pay is over \$200, it is set to missing. All 477 observations are used in the regressions reported in Tables 3 and 4. 
Table 3: Interval Regression Results of

Willingness to Pay for $\mathbf{5 0 \%}$ Reduction in Childhood Obesity

\begin{tabular}{|c|c|c|c|c|c|}
\hline & (1) & (2) & (3) & (4) & (5) \\
\hline \multirow[t]{2}{*}{ Age } & 1.44 & 1.26 & 0.40 & 1.91 & 0.12 \\
\hline & $(2.05)$ & (2.22) & (2.08) & (2.10) & (2.17) \\
\hline \multirow[t]{2}{*}{ Age Squared } & -0.02 & -0.01 & -0.00 & -0.02 & -0.00 \\
\hline & $(0.02)$ & $(0.02)$ & $(0.02)$ & $(0.02)$ & $(0.02)$ \\
\hline \multirow[t]{3}{*}{ White } & $22.63^{*}$ & -3.39 & -3.29 & 3.64 & 6.69 \\
\hline & $\mathrm{e}=.35$ & $\mathrm{e}=-.05$ & $\mathrm{e}=-.05$ & $\mathrm{e}=.05$ & $\mathrm{e}=.10$ \\
\hline & (12.85) & (13.81) & (13.51) & (13.01) & (13.78) \\
\hline \multirow[t]{2}{*}{ Female } & -3.24 & 8.93 & 9.52 & 10.83 & 3.88 \\
\hline & (11.73) & (13.22) & (12.69) & (12.33) & (12.40) \\
\hline \multirow[t]{3}{*}{ Obese } & $27.60 * *$ & 12.14 & 20.60 & $26.18 *$ & 14.89 \\
\hline & $\mathrm{e}=.17$ & $\mathrm{e}=.07$ & $\mathrm{e}=.12$ & $\mathrm{e}=.15$ & $\mathrm{e}=.09$ \\
\hline & (12.91) & (14.01) & (13.33) & (13.47) & (13.11) \\
\hline \multirow[t]{2}{*}{ Number of Kids in Household } & 7.32 & 9.68 & 9.50 & 7.58 & 5.21 \\
\hline & $(5.70)$ & $(6.16)$ & (5.90) & (6.03) & (5.95) \\
\hline \multirow[t]{3}{*}{ Household Income $>\$ 50,000$} & $35.39 * * *$ & $37.51 * * *$ & $33.64 * * *$ & $33.11 * *$ & $46.26 * * *$ \\
\hline & $\mathrm{e}=.39$ & $\mathrm{e}=.39$ & $\mathrm{e}=.36$ & $e=.35$ & $\mathrm{e}=.49$ \\
\hline & (12.46) & (13.54) & (12.94) & (12.82) & (13.05) \\
\hline \multirow[t]{3}{*}{ Believe Obesity is a Major Problem } & $48.99 * * *$ & & $115.81 * * *$ & & \\
\hline & $\mathrm{e}=.86$ & & $\mathrm{e}=2.00$ & & \\
\hline & $(18.44)$ & & (17.99) & & \\
\hline \multirow[t]{3}{*}{ Think Obesity Among Most Important Problems } & $39.20 * *$ & & & $66.61^{* * *}$ & \\
\hline & $\mathrm{e}=.18$ & & & $\mathrm{e}=.29$ & \\
\hline & (17.08) & & & (17.04) & \\
\hline \multirow[t]{3}{*}{ Think Obesity Among Least Important Problems } & $-62.73 * * *$ & & & $-94.02 * * *$ & \\
\hline & $\mathrm{e}=-.32$ & & & $\mathrm{e}=-.45$ & \\
\hline & (15.91) & & & (16.09) & \\
\hline \multirow[t]{2}{*}{ Prefer Large Public Health Budget for Obesity } & $40.68 * *$ & & & & $49.97 * * *$ \\
\hline & $\mathrm{e}=.35$ & & & & $\mathrm{e}=.42$ \\
\hline
\end{tabular}




\begin{tabular}{|c|c|c|c|c|c|}
\hline \multirow{3}{*}{ Prefer Small Public Health Budget for Obesity } & (16.79) & & & & $(17.43)$ \\
\hline & -22.86 & & & & $-62.16 * * *$ \\
\hline & $\mathrm{e}=-.19$ & & & & $\mathrm{e}=-.51$ \\
\hline \multirow{3}{*}{ Think Obesity Due to Individual Choice } & (17.10) & & & & (17.54) \\
\hline & -3.92 & & & & \\
\hline & $(14.27)$ & & & & \\
\hline \multirow[t]{2}{*}{ Think Obesity Due to Genetics } & 0.27 & & & & \\
\hline & (19.39) & & & & \\
\hline \multirow[t]{2}{*}{ Rate Tax Situation in NYS as Poor } & $-29.45^{* *}$ & & & & \\
\hline & $\mathrm{e}=-.35$ & & & & \\
\hline & (12.12) & & & & \\
\hline \multirow[t]{3}{*}{ Liberal } & $25.40^{*}$ & & & & \\
\hline & $\mathrm{e}=.20$ & & & & \\
\hline & (15.03) & & & & \\
\hline \multirow[t]{2}{*}{ Conservative } & -6.61 & & & & \\
\hline & $(16.43)$ & & & & \\
\hline \multirow[t]{3}{*}{ Democrat } & $32.81 * *$ & & & & \\
\hline & $\mathrm{e}=.32$ & & & & \\
\hline & $(14.31)$ & & & & \\
\hline \multirow[t]{2}{*}{ Republican } & 9.63 & & & & \\
\hline & $(17.82)$ & & & & \\
\hline \multirow[t]{2}{*}{ Constant } & -75.92 & -20.90 & $-90.61^{*}$ & -26.48 & 8.60 \\
\hline & $(56.82)$ & $(49.33)$ & $(48.21)$ & $(46.55)$ & $(51.52)$ \\
\hline Observations & 477 & 477 & 477 & 477 & 477 \\
\hline
\end{tabular}

Notes:

1) Elasticities appear below coefficient point estimates for coefficients that are ever statistically significant.

2) Reference person is non-white non-obese male with household income under $\$ 50,000$ per year who thinks youth obesity is either a minor problem or not a problem at all, thinks youth obesity is "somewhere in the middle" of all problems facing American youth, thinks youth obesity should receive an even share of the public health budget devoted to youth health problems, thinks obesity is primarily due to the environment, rates the tax situation in NYS as better than poor, and is a middle-of-the-road independent.

3) Standard errors appear in parentheses

4) Asterisks indicate statistical significance: ${ }^{* * *} \mathrm{p}<0.01$, ${ }^{* *} \mathrm{p}<0.05$, * $\mathrm{p}<0.01$

5) For more detail on independent variables, see Table 2 and the text. 
Table 3 (continued): Interval Regression Results of Willingness to Pay for $\mathbf{5 0 \%}$ Reduction in Childhood Obesity

\begin{tabular}{|c|c|c|c|c|c|}
\hline & $\begin{array}{l}\text { (1) } \\
\text { reprinted }\end{array}$ & (6) & (7) & (8) & (9) \\
\hline Age & $\begin{array}{c}1.44 \\
(2.05)\end{array}$ & $\begin{array}{l}1.05 \\
(2.21)\end{array}$ & $\begin{array}{c}1.85 \\
(2.17)\end{array}$ & $\begin{array}{l}1.06 \\
(2.21)\end{array}$ & $\begin{array}{c}1.32 \\
(2.22)\end{array}$ \\
\hline Age Squared & $\begin{array}{l}-0.02 \\
(0.02)\end{array}$ & $\begin{array}{l}-0.01 \\
(0.02)\end{array}$ & $\begin{array}{l}-0.02 \\
(0.02)\end{array}$ & $\begin{array}{l}-0.01 \\
(0.02)\end{array}$ & $\begin{array}{l}-0.01 \\
(0.02)\end{array}$ \\
\hline White & $\begin{array}{l}22.63 * \\
e=.35 \\
(12.85)\end{array}$ & $\begin{array}{c}-5.67 \\
e=-.08 \\
(13.62)\end{array}$ & $\begin{array}{c}4.20 \\
e=.06 \\
(13.88)\end{array}$ & $\begin{array}{c}0.85 \\
\mathrm{e}=.01 \\
(13.80)\end{array}$ & $\begin{array}{c}11.59 \\
\mathrm{e}=.17 \\
(13.92)\end{array}$ \\
\hline Female & $\begin{array}{c}-3.24 \\
(11.73)\end{array}$ & $\begin{array}{c}5.41 \\
(13.08)\end{array}$ & $\begin{array}{c}2.25 \\
(13.28)\end{array}$ & $\begin{array}{c}3.23 \\
(13.22)\end{array}$ & $\begin{array}{c}4.39 \\
(13.03)\end{array}$ \\
\hline Obese & $\begin{array}{c}27.60 * * \\
\mathrm{e}=.17 \\
(12.91)\end{array}$ & $\begin{array}{c}16.06 \\
\mathrm{e}=.09 \\
(14.19)\end{array}$ & $\begin{array}{c}14.20 \\
\mathrm{e}=.08 \\
(14.08)\end{array}$ & $\begin{array}{c}10.61 \\
e=.06 \\
(14.05)\end{array}$ & $\begin{array}{c}10.76 \\
e=.06 \\
(13.92)\end{array}$ \\
\hline Number of Kids in Household & $\begin{array}{c}7.32 \\
\mathrm{e}=.13 \\
(5.70)\end{array}$ & $\begin{array}{l}11.13^{*} \\
\mathrm{e}=.18 \\
(6.11)\end{array}$ & $\begin{array}{l}10.22 * \\
\mathrm{e}=.17 \\
(6.19)\end{array}$ & $\begin{array}{c}10.90 * \\
\mathrm{e}=.33 \\
(5.97)\end{array}$ & $\begin{array}{l}10.87^{*} \\
\mathrm{e}=.42 \\
(6.38)\end{array}$ \\
\hline Household Income $>\$ 50,000$ & $\begin{array}{c}35.39 * * * \\
\mathrm{e}=.39 \\
(12.46)\end{array}$ & $\begin{array}{c}33.23^{* *} \\
\mathrm{e}=.35 \\
(13.59)\end{array}$ & $\begin{array}{c}37.03 * * * \\
\mathrm{e}=.39 \\
(13.42)\end{array}$ & $\begin{array}{c}31.59 * * \\
\mathrm{e}=.33 \\
(13.58)\end{array}$ & $\begin{array}{c}39.65 * * * \\
\mathrm{e}=.42 \\
(13.42)\end{array}$ \\
\hline Believe Obesity is a Major Problem & $\begin{array}{c}48.99 * * * \\
\text { e }=.86 \\
(18.44)\end{array}$ & & & & \\
\hline Think Obesity Among Most Important Problems & $\begin{array}{c}39.20 * * \\
\mathrm{e}=.18 \\
(17.08)\end{array}$ & & & & \\
\hline Think Obesity Among Least Important Problems & $\begin{array}{c}-62.73 * * * \\
\mathrm{e}=-.32 \\
(15.91)\end{array}$ & & & & \\
\hline Prefer Large Public Health Budget for Obesity & $40.68 * *$ & & & & \\
\hline
\end{tabular}




\begin{tabular}{|c|c|c|c|c|c|}
\hline Prefer Small Public Health Budget for Obesity & $\begin{array}{c}\mathrm{e}=.35 \\
(16.79) \\
-22.86 \\
\mathrm{e}=-.19 \\
(17.10)\end{array}$ & & & & \\
\hline Think Obesity Due to Individual Choice & $\begin{array}{l}-3.92 \\
\mathrm{e}=-.05 \\
(14.27)\end{array}$ & $\begin{array}{c}-41.62 * * * \\
\mathrm{e}=-.52 \\
(15.76)\end{array}$ & & & \\
\hline Think Obesity Due to Genetics & $\begin{array}{l}0.27 \\
\mathrm{e}=.00 \\
(19.39)\end{array}$ & $\begin{array}{l}-38.67^{*} \\
\mathrm{e}=-.11 \\
(21.11)\end{array}$ & & & \\
\hline Rate Tax Situation in NYS as Poor & $\begin{array}{c}-29.45 * * \\
\mathrm{e}=-.35 \\
(12.12)\end{array}$ & & $\begin{array}{c}-46.60 * * * \\
\mathrm{e}=-.53 \\
(13.45)\end{array}$ & & \\
\hline Liberal & $\begin{array}{l}25.40^{*} \\
\mathrm{e}=.20 \\
(15.03)\end{array}$ & & & $\begin{array}{l}40.05^{* *} \\
\mathrm{e}=.30 \\
(16.19)\end{array}$ & \\
\hline Conservative & $\begin{array}{c}-6.61 \\
(16.43)\end{array}$ & & & $\begin{array}{c}-18.83 \\
(16.72)\end{array}$ & \\
\hline Democrat & $\begin{array}{l}32.81^{* *} \\
\mathrm{e}=.32 \\
(14.31)\end{array}$ & & & & $\begin{array}{l}27.41^{*} \\
\mathrm{e}=.26 \\
(15.06)\end{array}$ \\
\hline Republican & $\begin{array}{l}9.63 \\
\mathrm{e}=.05 \\
(17.82)\end{array}$ & & & & $\begin{array}{l}-34.51^{*} \\
\mathrm{e}=-.18 \\
(18.55)\end{array}$ \\
\hline Constant & $\begin{array}{l}-75.92 \\
(56.82)\end{array}$ & $\begin{array}{l}15.53 \\
(50.84)\end{array}$ & $\begin{array}{c}-8.68 \\
(48.43)\end{array}$ & $\begin{array}{l}-22.50 \\
(48.56)\end{array}$ & $\begin{array}{l}-38.92 \\
(51.03)\end{array}$ \\
\hline Observations & 477 & 477 & 477 & 477 & 477 \\
\hline
\end{tabular}

Notes:

1) Elasticities appear below coefficient point estimates for coefficients that are ever statistically significant.

2) Reference person is non-white non-obese male with household income under $\$ 50,000$ per year who thinks youth obesity is either a minor problem or not a problem at all, thinks youth obesity is "somewhere in the middle" of all problems facing American youth, thinks youth obesity should receive an even share of the public health budget devoted to youth health problems, thinks obesity is primarily due to the environment, rates the tax situation in NYS as better than poor, and is a middle-of-the-road independent. 
3) Standard errors appear in parentheses

4) Standard errors appear in parentheses

5) Asterisks indicate statistical significance: $* * * \mathrm{p}<0.01$, $* * \mathrm{p}<0.05,{ }^{*} \mathrm{p}<0.01$ 